\title{
Nutrition-Related Policy Fundamentals for Supporting Older Adults in the Community during a Pandemic: Lessons from COVID-19
}

Corresponding Author:

Meredith Whitmire, JD

Defeat Malnutrition Today; mponder@matzblancato.com

Co-Authors:

Mary Beth Arensberg, PhD, RDN

Abbott Nutrition; mary.arensberg@abbott.com

Alexandra Ashbrook, JD, LL.M.

Food Research \& Action Center; aashbrook@frac.org

Robert Blancato, MPA

Defeat Malnutrition Today; rblancato@matzblancato.com

\begin{abstract}
Nutrition is a key factor supporting healthy aging. Yet during the global COVID-19 pandemic, issuances of shelter-in-place orders, closures of senior centers and other congregate dining locations, losses of income, increases in grocery prices, and other changes have left many older adults struggling to maintain good nutrition. However, there are available solutions to improve the nutrition of millions of older adults who may be challenged to put food on the table. This commentary outlines the problems of older adult malnutrition and food insecurity and their strong correlation with COVID-19. It summarizes existing federal nutrition programs for older adults, including the U.S. Department of Health and Human Services' Older Americans Act (OAA) nutrition programs and the U.S. Department of Agriculture's means-tested nutrition programs such as the Supplemental Nutrition Assistance Program (SNAP). The commentary also contains lessons from community-based OAA nutrition programs that refocused some of their nutrition services and other supportive services during the COVID-19 pandemic to better serve socially distancing, newly homebound old-
\end{abstract}


er adults. It explores pre- and post-COVID-19 policy actions and opportunities for improving the nutrition, health, and well-being of community-dwelling older Americans during the current pandemic and beyond, including the need for more federal funding and flexibility for older adult nutrition programs, the need for improvements to older adult access to these programs, and the need for more older adult nutrition screening and intervention.

Keywords: malnutrition, food insecurity, Older Americans Act (OAA), Supplemental Nutrition Assistance Program (SNAP)

\section{Fundamentos de las políticas relacionadas con la nutrición para apoyar a los adultos mayores en la comunidad durante una pandemia: lecciones de COVID-19}

\section{RESUMEN}

La nutrición es un factor clave que favorece un envejecimiento saludable. Sin embargo, durante la pandemia mundial de COVID-19, la emisión de pedidos de refugio en el lugar, los cierres de centros para personas mayores y otros lugares para cenar congregados, la pérdida de ingresos, los aumentos en los precios de los comestibles $\mathrm{y}$ otros cambios han dejado a muchos adultos mayores luchando por mantener una buena nutrición. Sin embargo, existen soluciones disponibles para mejorar la nutrición de millones de adultos mayores que pueden tener el desafío de poner comida en la mesa. Este comentario describe los problemas de desnutrición e inseguridad alimentaria de los adultos mayores y su fuerte correlación con COVID-19. Resume los programas de nutrición federales existentes para adultos mayores, incluidos los programas de nutrición de la Ley de Estadounidenses Mayores (OAA) del Departamento de Salud y Servicios Humanos de EE. UU. Y los programas de nutrición de prueba de recursos del Departamento de Agricultura de EE. UU., Como el Programa de Asistencia Nutricional Suplementaria (SNAP). El comentario también contiene lecciones de los programas de nutrición de la OAA basados en la comunidad que reenfocaron algunos de sus servicios de nutrición y otros servicios de apoyo durante la pandemia de COVID-19 para servir mejor a los adultos mayores que se están distanciando socialmente y que están recién confinados a sus hogares. Explora las acciones y opor- 
tunidades de políticas anteriores y posteriores al COVID-19 para mejorar la nutrición, la salud y el bienestar de los estadounidenses mayores que viven en la comunidad durante la pandemia actual y más allá, incluida la necesidad de más fondos federales y flexibilidad para los adultos mayores. programas de nutrición, la necesidad de mejorar el acceso de los adultos mayores a estos programas y la necesidad de más evaluaciones e intervenciones nutricionales para los adultos mayores.

Palabras clave: desnutrición, inseguridad alimentaria, Ley de Estadounidenses Mayores (OAA), Programa de Asistencia Nutricional Suplementaria (SNAP)

\section{用于在大流行中支持社区老年人营养的政策 基础：从2019冠状病毒病得出的经验}

摘要

营养是支持健康老龄化的一个关键因素。不过，在2019冠状 病毒病（COVID-19）全球大流行期间，居家令的颁布、老年 中心和其他集体进餐地点的关闭、收入损失、杂货价格上 涨、以及其他变化已让许多老年人无法顺利维持良好营养。 不过，就提升在供应饮食起居一事上有困难的千万老年人的 营养状况而言，存在可用的解决措施。本篇评论文概述了老 年人营养不良和粮食不安全的问题以及其与COVID-19之间的 强烈联系。本文总结了针对老年人的现有联邦营养计划, 包 括美国卫生与公众服务部的《美国老年人法案》（OAA）营 养计划以及美国农业部按收入调查结果发放的营养计划, 例 如补充营养援助计划（SNAP）。本文还包括了从基于社区 OAA营养计划得出的经验, 这些营养计划在COVID-19大流行 期间重新聚焦于部分营养服务和其他支持性服务，以期更好 地为保持社交距离的、新居家的老年人提供服务。本文探究 了 COVID-19前后期的政策行动和机遇, 用于在当前大流行和 之后的时期改善居住在社区的美国老年人的营养、卫生和福 祉, 这包括需要对老年营养计划注入更多的联邦资金和灵活 性、需要改善老年人对这些计划的获取、需要开展更多的老 年人营养篮查及干预。

关键词: 营养不良, 粮食不安全, 《美国老年人法案》

（OAA），补充营养援助计划（SNAP） 


\section{Introduction}

$\mathrm{N}$

utrition is a key factor supporting healthy aging. Yet during the global COVID-19 pandemic, issuances of shelter-in-place orders, closures of senior centers and other congregate dining locations, losses of income, increases in grocery prices, and other changes left many older adults struggling to maintain good nutrition.

Prior to the pandemic, poor nutritional status-specifically protein-calorie malnutrition-and food insecurity were already growing crises among older adults in the United States (U.S.). Up to one out of every two older Americans is at risk for malnutrition (Kaiser et al., 2010; Izawa et al., 2006). Approximately 7.3 percent (5.3 million) of older adults aged 60 and older were food insecure in 2018 (Feeding America, 2020). During the COVID-19 pandemic, rates of food insecurity became substantially elevated (Food Research \& Action Center, Schanzenbach, 2020).

However, there are available solutions to improve the nutrition of millions of older adults challenged to put food on the table. This commentary outlines the problems of older adult malnutrition and food insecurity and the interrelations with COVID-19, summarizes existing federal nutrition programs for older adults and lessons from community-based nutrition programs that refocused some of their services during the COVID-19 pandemic, and finally explores pre- and post-COVID-19 policy actions and opportunities for improving the nutrition, health, and well-being of community-dwelling older Americans during the current pandemic and beyond.

\section{Older Adult Malnutrition and Food Insecurity}

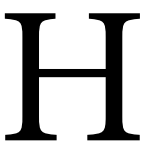
ealthy aging depends on good nutrition. However, as the World Health Organization has identified, older people are particularly vulnerable to malnutrition (World Health Organization, 2020). The United Nations Sustainable Development Goal Target 2.2 specifically states, "By 2030, end all forms of malnutrition, [...] and address the nutritional needs of [... older persons." (United Nations, 2020) because addressing older adult malnutrition can benefit both the older adult population and society. Malnutrition can be defined as a state of deficit, excess, or imbalance in protein, energy, and/or other nutrients that impacts body form, function, and clinical outcomes (Soeters et al., 2009). For older adults, protein malnutrition and loss of lean body mass are significant problems even among individuals who may be overweight or obese.

Malnutrition is prevalent in the U.S. today. A report by the Congressional Research Service documented "malnutrition affects 35 percent to 60 percent of older residents in long term care facilities and as many as 60 percent of hospitalized older adult patients in the U.S." (Dabrowska, 2017). Further, malnutrition affects approximately 20 percent to 50 percent of admitted hospital patients (Barker et al., 2011). 
There are a number of factors COVID-19 as well, and may be amplicontributing to older adult malnutri- fied by the virus itself and social imtion (Figure 1). Many of these may pacts related to the pandemic. place older adults at increased risk for

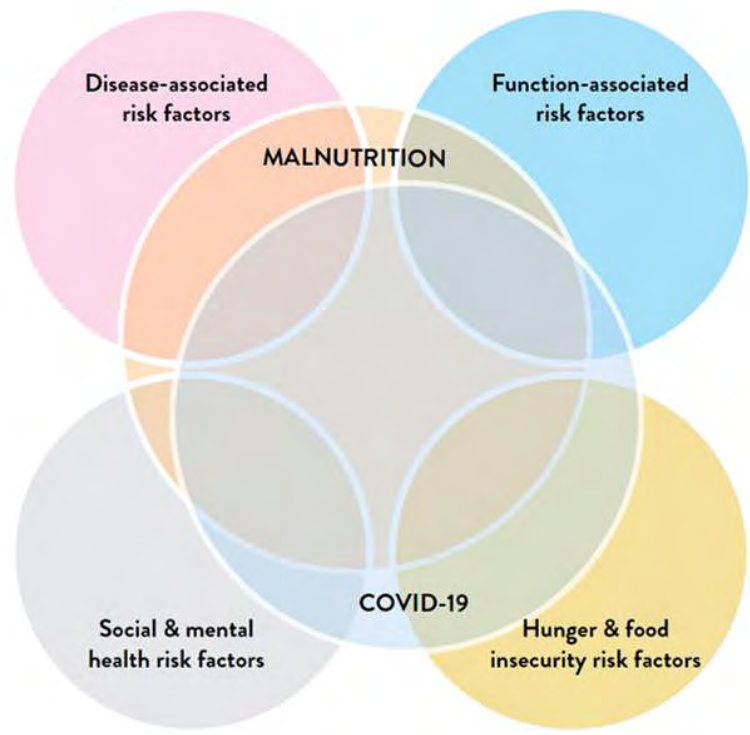

Figure 1: Overlapping risk factors for malnutrition and COVID-19 in older adults

Specifically, three in four Americans aged 65 years and older have multiple chronic conditions (Gerteis et al., 2014). Chronic diseases such as cancer, diabetes, and gastrointestinal, pulmonary, and heart disease and their treatments (including multiple medications) may lead to changes in nutrient intake and utilization, which can contribute to malnutrition (Wells et al., 2006). These same chronic conditions are among those that have also been identified as increasing the risk of severe illness from COVID-19 (CDC, 2020).

Function-associated risk factors for malnutrition related to aging can include loss of appetite and a more limited ability to chew or swallow, all of which can lead to malnutrition. For patients with COVID-19, gastrointestinal symptoms ranging from anorexia to nausea/vomiting and diarrhea have frequently been reported (Aguila et al., 2020) and similarly may contribute to malnutrition. Indeed, evidence shows the severity of COVID-19 infection is compounded by its effect on nutrition, especially for the critically ill (Aguila et al., 2020).

Age-related cognitive and functional decline can lead to social and mental health risk factors including social isolation and/or depression. The malnutrition risks from social isolation and poor mental health have been exacerbated by the community lock downs and stay-at-home orders put in place during the pandemic, as well as the vol- 
untary but necessary social distancing measures taken by older adults (Naja et al., 2020).

Finally, food insecurity and access to adequate nutrition are a fourth category of risk factors for malnutrition and older adults-particularly those who live alone-can be more likely to experience food insecurity (The Malnutrition Quality Collaborative, 2020). The United States Department of Agriculture (USDA) defines food insecurity as "a household-level economic and social condition of limited or uncertain access to adequate food" (USDA, 2019).

Millions of older Americans face food insecurity every day. Prior to the pandemic, approximately 7.3 percent (5.3 million) of older adults aged 60 and older were food insecure (Feeding America, 2020). During the COVID-19 pandemic, rates of food insecurity were substantially elevated, with Black and Latinx families facing disproportionately high rates (Food Research \& Action Center, Schanzenbach, 2020). Unfortunately, as the COVID-19 pandemic has disrupted markets worldwide, it has also increased food insecurity for many (World Bank, 2020).

Research shows that food insecurity rates tend to be higher for older adults who are: low income; less educated; Black or Latinx; separated, divorced, or never married; residing in the southern region of the U.S.; unemployed; living with a disability; living alone or with children; and a younger-aged older adult (Food Research \& Action Center, 2019; Strickhouser et al., 2014; Ziliak et al., 2016). The COVID-19 pandemic added further risk factors for food insecurity as economic insecurity increased and the health guidance of staying home, minimizing contact with large groups, and stocking up on food and supplies confronted the many older adults who relied on group meals at senior centers and/or food from local food banks and could not afford to purchase several weeks of food (Goger, 2020). One recent study identified that less than one in five (18.8 percent) of adults with very low food security were able to comply with public health recommendations to purchase two weeks of food at a time (Wolfson and Leung, 2020).

Having reliable access to enough food and healthy food is important for everyone, but is particularly important as people age. Unfortunately, older adults with food insecurity have lower overall dietary quality than food-secure older adults, as measured by USDA's Healthy Eating Index. They consume fewer calories, less protein, and fewer essential vitamins and minerals, versus their food-secure peers (Lee and Frongillo, 2001; Montoya et al., 2011; The Malnutrition Quality Collaborative, 2020; Eggersdorfer et al., 2018). Poor diet quality increases the risk for malnutrition, which could make older adults more susceptible to a pandemic virus and its systemic effects. In addition, food insecurity has been identified as increasing risk for chronic health conditions, even when controlling for income (Feeding America and National Foundation to End Senior Hunger, 2014; Feeding America, 2020). 


\section{Older Adult Nutrition, Healthcare Outcomes, and the COVID-19 Pandemic}

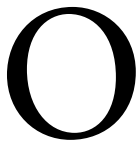
lder adults are at increased risk for both contracting and developing more severe complications from acute respiratory viruses such as COVID-19. Older adults are also at increased risk for poor nutrition or malnutrition. Taken together, these threats combine to increase the vulnerability of older adults during a pandemic and potentially may have longer-lasting implications. Indeed, the authors of the 2020 Global Nutrition Report stated, "Malnutrition is a threat-multiplier [...] If no action is taken, the effects of the current COVID-19 pandemic will only make it harder for vulnerable populations to protect themselves against malnutrition" (World Health Organization, 2020).

When left untreated, malnutrition can adversely impact multiple health outcomes. Malnourished older adults make more visits to physicians, hospitals, and emergency rooms (Izawa et al., 2006). They are also more likely to develop a healthcare-acquired condition including pressure injuries, have delayed wound healing, decreased respiratory and cardiac function, muscle wasting and functional loss increasing the risk of falls, longer length of hospital stay, higher readmission rates, and higher treatment costs (Tappenden et al., 2013; Ishida et al., 2020; Sharma et al., 2017; Lee et al., 2015; Zellner et al., 2019).

Nutrition plays a critical role in immunity and malnutrition can lead to increased infection rates and immune suppression (The Malnutrition Quality Collaborative, 2020). The basal immune dysfunction that occurs in malnourished patients has been identified as a virulence factor for COVID-19 and could make older adults more susceptible to the virus as well as to its systemic effects (Figure 2) (Briguglio et al., 2020).

Early in the pandemic, a potentially higher prevalence of malnutrition among older patients admitted to the hospital with COVID-19 was identified; Li et al. in Wuhan, China, documented that 52.7 percent of older adults with COVID-19 were malnourished and 27.5 percent were at risk of malnutrition (2020). Li et al. proposed several potential reasons for the high malnutrition rates, including increased need for protein resulting from acute inflammatory response, diabetes comorbidity, COVID-19 gastrointestinal symptoms, and poor appetite because of patient anxiety. Malnutrition has remained an issue over the course of hospitalizations too, with most patients admitted to intensive care with COVID-19 identified as acutely malnourished (Jin et al., 2020 ) and 45 percent of patients admitted to a rehabilitation unit following COVID-19 infection identified as high risk for malnutrition (Brugliera et al., 2020).

Malnutrition's health impacts, particularly on respiratory and cardiac function, can likely affect the course of recovery of patients with COVID-19. Specifically, prolonged hospitalization following the catabolism and immobilization that can occur in COVID-19 


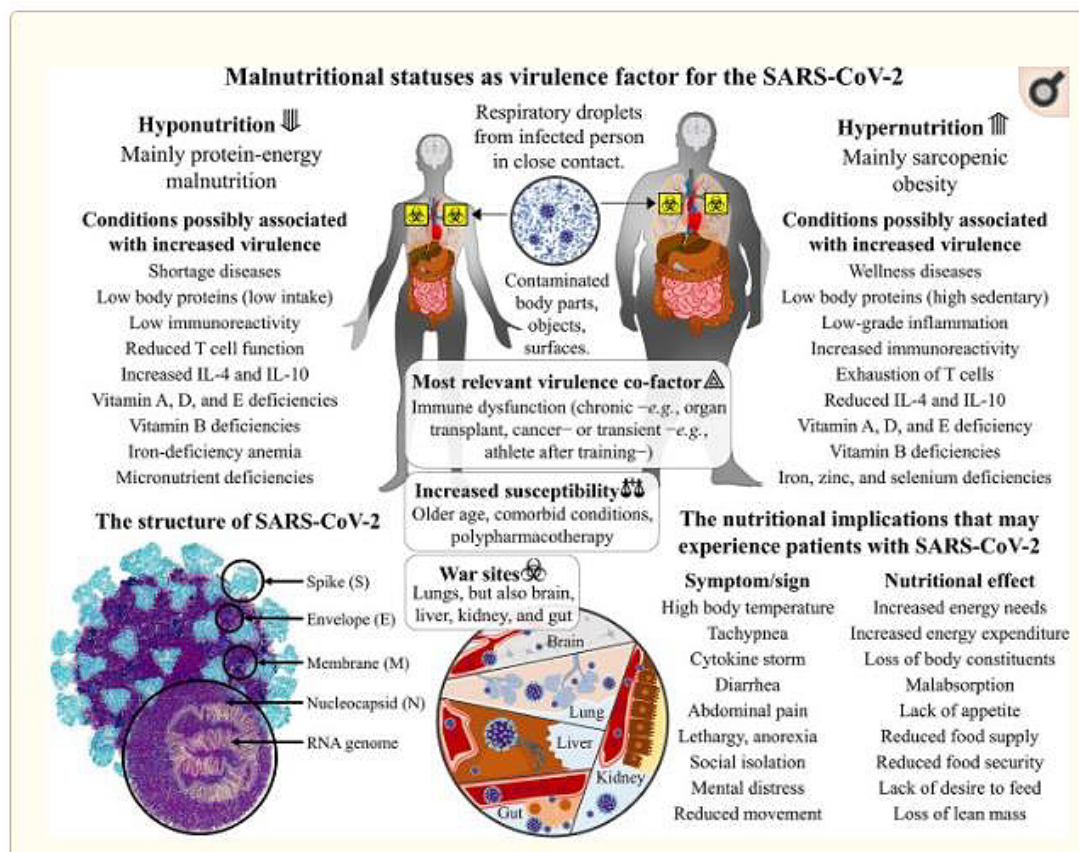

Figure 1

The SARS-CoV- 2 virulence and the malnutritional status of the human host: immune-based dysfunctions in hypo- and hypernutrition. The severe acute respiratory syndrome coronavirus that was discovered in Hubei province, China, at the end of December 2019 (SARS-CoV-2) is a single-strand positive-sense RNA wirus with the encoding potential of four structural proteins: the spike (S), the envelope $(E)$, the membrane $(M)$, and the nucleocapsid (N). It spreads through respiratory droplets of infected patients that can deposit on body parts and fomites. The basal immune dysfunction that exists in protein-energy malnutrition and sarcopenic obesity can make individuals more susceptible to SARS-CoV-2 contraction and affections. Other than the collapse of alveoli and respiratory failure, the coronavirus replication leads to systemic consequences in the brain, liver, kidneys, and gut. Once affected, malnourished individuals will have fewer body reservoirs and immune potential to fight for recovery.

Figure 2

induces weight and muscle mass loss, leading to sarcopenia, which in turn contributes to reduced respiratory and cardiac function, extended hospitalization, and poorer prognosis (Ferrara et al., 2020). Sarcopenia itself is also a risk factor for malnutrition (Brugliera et al., 2020). Thus, it is not surprising nutrition status has been identified as an important factor influencing the outcome of COVID-19 patients (Laviano et al., 2020). Guidance documents emphasize that identifying and addressing malnutrition is critical for treating and preventing further adverse health outcomes from COVID-19 (Handu et al., 2020) and nutrition is among the recommended treatments for post-acute COVID-19 syndrome (Nalbandian et al., 2021). There is also emerging evidence that maintaining adequate levels of certain key nutrients, such as vitamin $\mathrm{D}$, may help lower risk or aid recovery from severe COVID-19 for some people (Meltzer et al., 2020; Hernandez et al., 2020). 


\section{Addressing Malnutrition and Food Insecurity in Healthcare Settings}

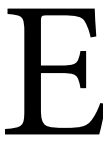

ven though malnutrition and food insecurity are common problems for older adults, they are not systematically identified or treated across the continuum of care. In an analysis by the U.S. Agency for Healthcare Research and Quality (AHRQ), malnutrition was diagnosed in only about 8 percent of hospital stays (Barrett et al., 2018). Yet as previously mentioned, it likely exists in up to 60 percent of hospitalized older adults (Dabrowska, 2017). Similarly, malnutrition is diagnosed in just 3.6 percent of older adult emergency department visits (Lanctin et al., 2019), but its prevalence is estimated to be much higher, between 12-16 percent (Pereira et al., 2015; Vivanti et al., 2015). In the community setting, identification of malnutrition is even less common, perhaps in part because comprehensive nutrition assessment and intervention, as an integrated part of overall healthcare delivery, may not be available at the community level (Dwyer et al., 2020). Russell (2019) identified multiple barriers to community-level malnutrition screening and intervention, specifically not having a validated nutrition screening tool, staff not referring at-risk clients, clients not receptive to nutrition services, care managers lacking awareness of malnutrition and its impact on older adults, and cost prohibitive out-patient nutrition counseling.

One of the ways to improve malnutrition screening and intervention care processes is through the implementation of a quality improvement initiative. The Malnutrition Quality Improvement Initiative (MQii) was developed to support quality improvement for malnutrition care and has developed an interdisciplinary toolkit that aligns with the nutrition clinical process (See Appendix 1) (Malnutrition Quality Improvement Initiative, 2020).

Part of these process improvements is the early initiation of a dietitian consult and malnutrition-risk diet order (with food and/or oral nutrition supplements for at risk patients) as well as connecting patients to federal nutrition programs and food resources available in their community. Similarly, nutrition-focused quality improvement initiatives for malnutrition have included early nutrition intervention with oral nutrition supplements and reported results document significant reductions in 30-day readmissions, lengths of hospital stay, overall healthcare resource use (e.g., hospitalization, emergency department, and outpatient visits), and cost savings (Sulo et al., 2017; Sulo et al., 2017, May 1-4; Riley et al., 2020). Early nutrition intervention, including oral nutrition supplements, has also been a hallmark of the few available articles that address nutrition care for hospital and rehabilitation patients with COVID-19 (Jin et al., 2020; Zhang et al., 2020).

Advocating for appropriate and timely nutrition can help improve clinical outcomes as well as reduce or prevent malnutrition's impact on patients with COVID-19 (Handu et al., 2020). Thus, an important policy implication 
to help prepare for the future, as identified in the National Blueprint: Achieving Quality Malnutrition Care for Older Adults, 2020 Update, is to "[i]nclude malnutrition care standards in health pandemic and emergency preparedness pathways" (The Malnutrition Quality Collaborative, 2020).

Further, there is growing awareness and acknowledgment that health outcomes and disparities are often driven by social determinants of health rather than by medical care alone (Heiman et al., 2015). Social determinants of health include social, economic, physi$\mathrm{cal}$, and other conditions where people live, learn, work, and play that influence their health and health outcomes (HHS ODPHPH, 2020a). Poverty and food insecurity are social determinants of health and are associated with serious and costly health problems. Similarly, poverty and food insecurity also contribute to health disparities among older adults (Bernstein and Munoz, 2012).

Older adults living in food-insecure households do not have access to nutritious foods on a regular basis and are at higher risk for negative physi- cal and mental conditions, including chronic diseases such as diabetes, congestive heart failure, and hypertension, limitations in activities of daily living, and depression (Redmond et al., 2016; lyles et al., 2014; Gundersen and Ziliak, 2017; Portela-Parra and Leung, 2019). Further, food insecurity is significantly associated with obesity, particularly for women (Nettle et al., 2017) and evidence has identified that obesity is a risk factor for COVID-19 complications and should be considered in the management of COVID-19 (Nakeshbandi et al., 2020).

Food insecurity and multimorbidity are said to create a negative feedback loop. For some older adults, food insecurity increases morbidity risk, particularly conditions that are sensitive to diet or medication adherence as food insecure older adults must frequently make the difficult choice between either healthy food or medications (Box 1). Certainly, the potential for medication underuse should be a consideration for food insecure older adults receiving medical treatments during a pandemic (Afulani, 2015).

Box 1: Food-insecure older adults often have cost-related medication underuse*

Rates of cost-related medication underuse for adults aged 65 and over are:

- $25 \%$ for those experiencing marginal food security (low level of food insecurity);

- $40 \%$ for those experiencing low food security; and

- $56 \%$ for those experiencing very low food security (most severe level of food insecurity).

${ }^{*}$ Cost-related medication defined as saving money by skipping medications, taking less medicine than prescribed, delaying filling a prescription, and/or requesting lower cost medications and not being able to afford medicine due to cost. 
For other older adults, it is likely poor health increases their risk for food insecurity as the out-of-pocket medical costs associated with poor health impact their food budgets and functional impairments make managing their chronic disease more challenging and expensive (Pooler et al., 2019). Jih et al. (2018) reported that a heavy chronic disease burden likely exerts substantial pressure on older adults' household budgets, increasing risk for food insecurity. Thus, there is the potential that the medical costs associated with older adults contracting COVID-19 or other pandemic disease may lead to food insecurity and its related nutritional challenges.

It is not surprising then that food insecurity is a strong predictor of increased health care needs and costs. Garcia et al. (2018) documented that food insecure older adults have higher healthcare costs than food-secure older adults and that "on average, food insecurity added about 11 percent to the health care costs of older adults with and without a specific chronic condition." Food insecure older adults also have greater utilization of healthcare services, including higher odds of more office visits, emergency room visits, and hospitalizations (Bhargava \& Lee, 2016). Further, food insecurity, as identified in Healthy People 2030, is a key issue in economic stability (HHS ODPHP, 2020b).

Because food insecurity impacts health and many older adults have frequent health visits, healthcare providers can play a critical role in impacting food insecurity, even during a pandemic. Suggested actions include regularly screening patients, intervening clinically, and advocating for systems change (Pooler et al., 2019). The Food Research \& Action Center and the AARP Foundation have created a food security screening module for providers that might be useful (2018).

Pooler et al (2019) identified screening programs as essential, since food insecurity may be episodic and often hidden from view. The Hunger Vital $\mathrm{Sign}^{\mathrm{TM}}$ is a 2 -item validated screening tool that can be used; it is highly sensitive and specific among older adult populations (Gundersen et al., 2017). The COVID-19 pandemic's resulting increased food insecurity risk underscores the need for systematic screening of older adults in the community for food insecurity.

A clinician's familiarity with local community resources and publicly and privately funded nutrition programs (such as those described in more detail in the next section) is fundamental for ensuring effective interventions. Clinicians and health systems are in a unique position to address barriers such as lack of eligibility awareness and stigma by reframing food assistance as a benefit that can support health and independence (Pooler et al., 2019). Creating systems that support timely referrals and stay current, particularly during a pandemic when program requirements and offerings often change quickly, will likely benefit older adults the most.

As the older population continues to increase in size, so too will the 
number of older adults who are at risk for food insecurity. Clinicians' experiences in treating food-insecure patients can offer important insights for policy leaders. Advocating for more systematic screening, documentation in the medical record, and referrals to and adequate funding of federal nutrition and community programs will help build the framework needed to support a burgeoning older adult population (Pooler et al., 2019). This same framework will help strengthen the resources needed to face future pandemics.

\section{Community-based, Federally- Funded Nutrition Services for Older Adults}

I he U.S. federal government funds several types of nutrition services for older adults who may be at risk for malnutrition (See Appendix 2). Some of these programs are "means-tested" (provided only to older adults with lower incomes), while other programs are open to all older adults regardless of income level.

The USDA administers several means-tested programs for older adults. The Supplemental Nutrition Assistance Program (SNAP, formerly known as food stamps) provides monthly benefits to low-income households to purchase food and is the largest USDA food assistance program, serving more than 5 million older adults annually (U.S. Government Accountability Office, 2020). A considerable body of evidence shows that SNAP plays a role in improving food security, economic secu- rity, health, and dietary intake throughout the lifespan. For a comprehensive review of the literature, see the Food Research \& Action Center's SNAP and Public Health: The Role of the Supplemental Nutrition Assistance Program in Improving the Health and Well-Being of Americans.

Other USDA programs include the Commodity Supplemental Food Program (CSFP), which provides shelf-stable commodity foods delivered monthly to older adults, the Child and Adult Care Food Program (CACFP), which provides food to child-care and adult day care participants, and the Senior Farmers' Market Nutrition Program, which provides vouchers to low-income older adults to purchase fresh fruit and vegetables at farmers' markets and roadside stands (U.S. Government Accountability Office, 2020).

During the pandemic public health emergency, the various response bills have authorized "emergency" SNAP benefits. As implemented by USDA, additional allotments can go to SNAP households not already receiving the maximum SNAP benefit for households of their size. States had to seek waivers to be able to provide this emergency benefit allotment, and all states did. In addition, many states were approved for waivers streamlining application and recertification for SNAP (USDA, 2020a) and all states were approved by USDA for SNAP Online Purchasing Pilots. (USDA, 2020b). While these approvals are encouraging, there are still many barriers to overcomeincluding the limited number of food 
retailers currently able to participate in online SNAP purchasing-before these options are widely available to all interested older adults. CACFP waivers were also granted that allowed adult care centers to operate as non-congregate sites and loosened meal pattern requirements if there were any disruptions to the food supply.

Unlike most USDA programs which are means-tested, all older adults are eligible to participate in HHS nutrition programs regardless of income. However, unlike SNAP, which can expand during times of increased need to serve any eligible older adult, funding for HHS programs is capped. The HHS nutrition programs, also called the Older Americans Act Nutrition Services Programs, were established in 1972 and are authorized through the Older Americans Act (OAA). They include the OAA Title III-C-1 congregate nutrition program (meals provided at senior centers and other group locations) and the OAA Title III-C-2 home-delivered nutrition program (commonly known as "Meals on Wheels") (Colello, 2020). (A separate program under Title VI of the OAA provides nutrition services to older Native Americans through funding to tribes; unless otherwise noted, this article will discuss the Title III-C programs.)

The OAA nutrition programs are statutorily required to provide meals, nutrition education, nutrition counseling (as feasible) and other nutrition services. The intent of the OAA is to reduce food insecurity, hunger and malnutrition; enhance socialization; and promote health and well-being within a coordinated network of services and supports. Before the COVID-19 pandemic, the OAA nutrition programs served almost 2.4 million older adults annually; in federal fiscal year 2018, the OAA congregate nutrition program served 1.5 million older adults and the OAA home-delivered nutrition program served almost 900,000 older adults (Colello, 2020). Meals served as part of the OAA nutrition programs must meet one-third of the daily recommended dietary reference intakes (DRIs), helping to ensure the nutritional quality of the food served (Colello, 2020).

Even prior to the pandemic, federal nutrition programs played an important role in preventing and intervening for malnutrition among older adults, particularly among low-income older adults. For example, in a national survey of OAA nutrition program participants, 58 percent of respondents reported that the congregate nutrition program provided one-half or more of their daily food intake, as did 62 percent of home-delivered meals program participants who responded to the survey (Administration for Community Living, 2020). Further, 11 percent of congregate nutrition respondents and 19 percent of home-delivered nutrition respondents stated in their survey responses that they had an annual household income of $\$ 10,000$ or less, despite the programs not having an income requirement.

During the COVID-19 pandemic, the OAA nutrition programs became even more crucial for many older adults. 
Almost all congregate nutrition programs shut down entirely, converting their participants to either home-delivered meals recipients, "grab-and-go" meals recipients, or some combination of the two. Demand for meals grew dramatically; according to research conducted by Meals on Wheels America in late April 2020, 89 percent of home-delivered nutrition programs saw an increase in meal requests; of those, 79 percent reported that the number of new requests for meals at least doubled between February 2020 and April 2020. Meals on Wheels America also found in the April 2020 survey that home-delivered meals programs served 56 percent more meals and 22 percent more older adults per week in April 2020 compared to pre-pandemic levels.

In response to this unprecedented demand for services, Congress appropriated emergency supplemental funding for the OAA nutrition programs in March 2020 through two separate laws. The Families First Coronavirus Response Act provided a total of \$250 million in funding for OAA nutrition programs under Titles III-C and VI; the Coronavirus Aid, Response and Economic Security (CARES) Act provided a further $\$ 500$ million in funding (Colello, 2020b). Congress also appropriated $\$ 175$ million in December 2020 for the III-C program through the Consolidated Appropriations Act of 2020 and appropriated another $\$ 750$ million in March 2021 through the American Rescue Plan Act of 2021. As a point of reference, the Title III-C programs received approximately $\$ 951$ million in total funding in federal fiscal year 2021 and the Title VI nutrition program received approximately $\$ 34.7$ million the same year (Further Consolidated Appropriations Act, 2020).

\section{Pre-Pandemic Nutrition Policy Issues and Advocacy}

number of stakeholders are en-
gaged in the community-based
nutrition programs that directly provide food to older adults (Figure 3). Many of these stakeholders have also been active in advocating for and shaping the pre-COVID-19 nutrition care policy landscape as described further below.

One group that took a leading role in shaping the pre-COVID-19 nutrition care policy landscape is Defeat Malnutrition Today. This coalition formed in 2015 as a diverse alliance of national, state, and local stakeholders and organizations, including community, healthy aging, nutrition, advocacy, healthcare professional, faith-based, and private sector groups. Today it has over 100 members who share the goal of achieving the recognition of malnutrition as a key indicator and vital sign of older adult health (Defeat Malnutrition Today, 2020). In 2016, the coalition convened a Malnutrition Quality Collaborative of multi-stakeholder nutrition, healthy aging, and food security experts who broke new ground in releasing the first ever National Blueprint: Achieving Quality Malnutrition Care for Older Adults (The Malnutrition Quality Collaborative, 2017). The Blueprint outlined specific goals, strategies, and 


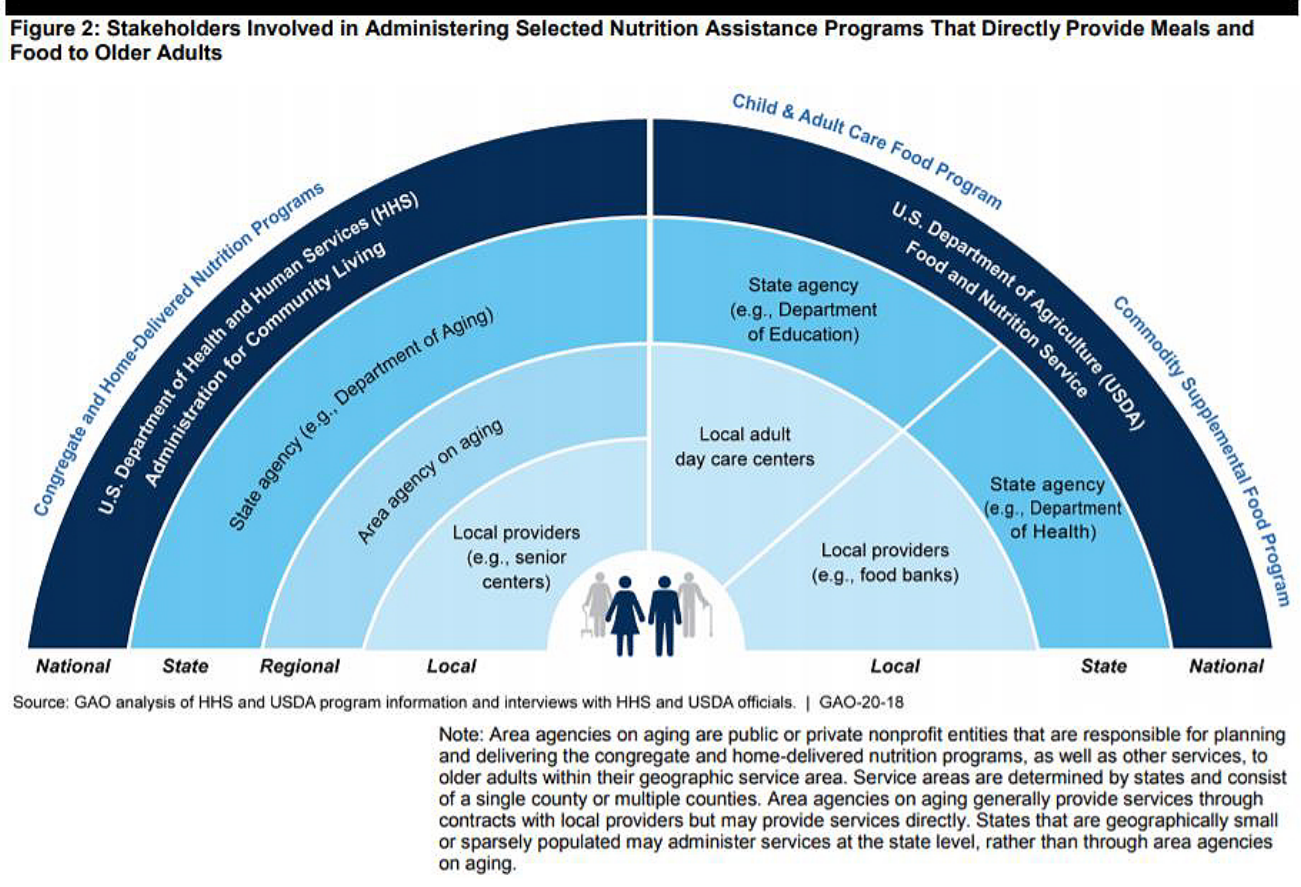

Figure 3: Stakeholders involved in administering selected nutrition assistance programs that directly provide meals and food to older adults (U.S. Government Accountability Office, 2019)

Table 1: Pandemic-related recommendations that support the goal of improving quality malnutrition care (The Malnutrition Quality Collaborative, 2020)

\begin{tabular}{|c|c|}
\hline Strategies & Recommendations \\
\hline $\begin{array}{l}\text { Identify Quality Gaps in } \\
\text { Malnutrition Care }\end{array}$ & $\begin{array}{l}\text { Recognize impact of malnutrition and } \\
\text { quality gaps for older adults in national, } \\
\text { state, and local population health and } \\
\text { chronic disease reports and action plans } \\
\text { (e.g., malnutrition prevention, identi- } \\
\text { fication, and treatment needs in acute } \\
\text { care, post-acute care, and home and } \\
\text { community-based settings, and among } \\
\text { priority disease-specific populations and } \\
\text { during health pandemics) }\end{array}$ \\
\hline \multirow[t]{2}{*}{$\begin{array}{l}\text { Establish and Adopt Quality } \\
\text { Malnutrition Care Standards }\end{array}$} & $\begin{array}{l}\text { - Establish care pathways for malnutrition } \\
\text { in all care settings during health pan- } \\
\text { demics and emergencies }\end{array}$ \\
\hline & $\begin{array}{l}\text { - Include malnutrition care standards in } \\
\text { institutional health pandemic and emer- } \\
\text { gency preparedness pathways }\end{array}$ \\
\hline
\end{tabular}


recommendations to impact older adult malnutrition (See Appendix 3).

Several recommendations in the Blueprint have been implemented since 2017; however, work remains as we have move into what the World Health Organization has declared as the Decade of Healthy Aging. Thus, an updated Blueprint was released in 2020, to be used as a guide for the new decade and provide specific recommendations for influencing the health outcomes of older adults. As referenced earlier in this paper, the updated Blueprint includes pandemic-related recommendations; these are specific to the Blueprint's Goal 1: Improve Quality Malnutrition Care (Table 1) (The Malnutrition Quality Collaborative, 2020).

Throughout our paper, older adult malnutrition has been described as a persistent and growing crisis in America today. This is in part because malnutrition care has been omitted from most prevention and wellness, patient safety and emergency preparedness, care transition, and population health strategies (The Malnutrition Quality Collaborative, 2020). One area where there has been some movement is in value-based and quality care.

Earlier we identified that the MQii has helped promote implementation of nutrition-focused quality improvement programs through launch of an interdisciplinary toolkit. The MQii has also supported development of the first ever malnutrition-specific electronic clinical quality measures (eCQMs). These malnutrition eCQMs have been adopted by numerous healthcare systems and hospitals throughout the U.S. (Academy of Nutrition and Dietetics, 2020) even though quality measures are still not required by the Center for Medicare \& Medicaid Services (CMS). However, CMS has acknowledged malnutrition care as a gap area and approved inclusion of malnutrition quality measures in two Qualified Clinical Data Registries (QCDRs) for 2020 in the Merit-Based Incentive Payment System (MIPS) (Appendix 4) (The Malnutrition Quality Collaborative, 2020). Adoption of malnutrition quality measures as well implementing best practices across the continuum of care, including through telehealth services, will go a long way in improving the standard of malnutrition care provided to older adults.

Evidence-based care standards and performance benchmarks are also needed to improve malnutrition care in post-acute care and community settings too. In 2019, the U.S. Government Accountability Office (GAO) completed a report, Nutrition Assistance Programs, Agencies Could Do More to Help Address the Nutritional Needs of Older Adults. The GAO identified that research shows nutrition can affect the health outcomes of older adults. However, federal nutrition guidelines only provide broad guidance for healthy populations and do not focus on the varying nutritional needs of older adults, even as the majority of older adults have chronic conditions often impacted by nutrition. The GAO report recommended HHS develop a plan to include specific guidelines for older adults in a future update of its Dietary Guidelines for Americans. 
Another recommendation was that HHS and USDA improve oversight of federally-funded meals programs and provide additional education and information to meals providers to help them meet older adults' diverse nutritional requirements (U.S. Government Accountability Office, 2019). USDA and HHS have largely concurred with these recommendations.

The post-acute care setting would benefit too from evaluations of specific community programs, such as home delivered meals, on patient health outcomes (Campbell et al, 2015; Thomas, 2015). This is especially important as CMS has now expanded opportunities for Medicare Advantage plans to offer benefits that address social needs, including a home-delivered meals benefit to enrollees with chronic conditions (Centers for Medicare and Medicaid Services, 2019). A 2019 research report from The Urban Institute and supported by the Robert Wood Johnson Foundation found meal delivery was the most commonly added or expanded Medicare Advantage social needs benefit and industry experts believed it to be of great interest to insurers (Skopec et al., 2019). However, widespread adoption has not yet occurred. If these benefits were more frequently provided, it would help to support community-based providers.

Prior to the pandemic, advocates also worked to secure adequate funding for SNAP. Of note, SNAP protects senior health and helps maintain independence. The health benefits that result from an adequate diet can support older adults in their efforts to remain active, socially integrated, and independent. Older adults can use SNAP at tens of thousands of locations across the nation-in regular commercial channels and without stigma-at grocery stores, retail outlets, and farmers' markets where older adults would normally purchase their food. SNAP provides older adults with additional food-purchasing power and can help mitigate the hardships of rising food costs for those with fixed incomes.

\section{Pandemic Nutrition Policy Issues and Advocacy}

fter the COVID-19 pandemic
had forced older adults to re-
main in their homes indefinitely, policymakers and providers at the national, state, and local levels had to innovate quickly in order to ensure that older adults could still receive proper nutrition access and care. During the pandemic, connecting older adults to USDA's SNAP was an essential strategy to address the pandemic's dual threats to health and economic security. SNAP is the only means-tested nutrition program available to all eligible older adults in every part of the country. Because of its entitlement structure, SNAP can reach any eligible older adult with a benefit that is 100 percent federally funded.

A considerable body of evidence shows that SNAP plays a role in improving food security, economic security, health, and dietary intake throughout a recipient's lifespan (Food 
Research \& Action Center, 2017). Multiple attributes of SNAP made it particularly responsive to the food security needs of low-income older adults and particularly suited to respond during a national health and economic crisis (Food Research \& Action Center, 2019). With escalating need, more older adults benefitted from SNAP during the pandemic; however, additional older adults struggling to put food on the table could have accessed SNAP. Further work is needed post-pandemic to help SNAP reach more older adults with an adequate benefit.

Some key proposals from advocates that would have provided more resources to help older adults access nutritious food during this crisis and jump start the economy included boosting the maximum SNAP benefit and basing it on a more adequate food plan and increasing the monthly minimum SNAP benefit from $\$ 16$ to $\$ 30$.

During the pandemic, states could also adopt policies and practices that can connect more older adults to SNAP. States could draw down federal reimbursement match funds to support SNAP information and application assistance efforts, including via non-profit groups' telephone help lines. Policies for greater SNAP access also often could promote social distancing. (Food Research \& Action Center, 2020). For example, key opportunities for state SNAP agencies to streamline the application and recertification process for older adults included providing a simplified application for older adults, ensuring access to telephonic interviews, implementing voice/telephonic signatures, promoting the best use of authorized representative opportunities, and adopting a standard medical deduction. Also, as discussed earlier in this article, states have implemented online grocery shopping for SNAP customers and as these models expand, more older adults will be able to benefit from the home delivery of groceries.

Regarding the HHS programs, as previously discussed, Congress appropriated emergency supplemental funding for the OAA nutrition programs in March 2020 through both the Families First Coronavirus Response Act and the CARES Act. This supplemental funding was instrumental in enabling community providers to serve the increase in demand.

Additionally, the emergency supplemental funding came with accompanying policy provisions that were crucial to sustain increased service levels. As explained previously, under the OAA, nutrition programs purchasing food with Titles III-C and/or VI funding are required to serve meals that meet the Dietary Guidelines for Americans and at least one-third of the DRI (Older Americans Act, 2020). However, a provision in the CARES Act allowed providers to waive the nutritional requirements for meals funded by emergency supplemental funding (CARES Act, 2020). Advocates asked for this provision to be included in the CARES Act because at the beginning of the pandemic, general food shortages were common and many food companies that routinely supplied these programs 
were unable to meet the significantlyincreased market demand for DGA/ DRI-compliant meals. Easing these restrictions enabled local programs to "shop around" and work with non-traditional food suppliers such as Nutrisystem meals (NANASP, 2020).

Another important policy provision was a waiver of the transfer authority limits within OAA funding. Under the OAA, states are allowed to transfer their allocated funding within OAA titles, but only up to a certain limit (Older Americans Act, 2020). For example, normally states may transfer up to 40 percent of their Title III-C funding for congregate and home-delivered nutrition, meaning that states could shift 40 percent of their total funding amount around to provide congregate programs with some of the home-delivered meals programs' funding or vice versa. In practice, in most states, home-delivered nutrition programs generally receive transferred funding from congregate nutrition programs since congregate nutrition programs receive more funding in their original allocations than home-delivered programs. (Administration for Community Living, 2019)

Because congregate nutrition program participants were converted to "grab and go" meal recipients and/or to home-delivered meals recipients, and neither of those programs are able to receive congregate funding (as all funding spent on non-congregate dining must be from the home-delivered nutrition "pot"), programs were suddenly faced with two problems: having congregate nutrition funding they could not spend and not having enough home-delivered nutrition funding to cover the new influx of participants. Advocates secured a waiver of the 40 percent transfer limit on nutrition funding, which solved both problems. Coupled with emergency authorities under the OAA for "major disaster" declarations by states, 100 percent of emergency nutrition funding and 100 percent of regular nutrition funding could then go straight to home-delivered nutrition programs, where the need was greatest.

Telehealth services have also become crucial because of the pandemic. Prior to the pandemic, there were already several nutrition health services that could be performed as telehealth services under Medicare, including medical nutrition therapy for certain chronic conditions (diabetes, renal disease, or post-kidney transplant).

During the pandemic, CMS had designated over 100 new services as eligible to be provided via telehealth out of an abundance of caution - the goal has been to keep older adults from making unnecessary trips out of their homes to healthcare providers (CMS, 2020). Though not specifically nutrition-oriented, some of these new services could include malnutrition and food insecurity screening and interventions, such as self-care management training and hospital discharge planning. Further services that might flag malnutrition or food insecurity include routine screening appointments and check-ins, skilled nursing facility discharge planning, end-stage renal disease appointments, and new/established home visit patient appointments. 
Wherever possible, healthcare providers should take the opportunity to screen older adults for malnutrition, food insecurity, and other nutritional issues and refer them to community services where needed to help provide adequate food, meal services, oral nutrition supplements, etc. to address important nutrition issues.

\section{In the Field: Senior Nutrition Program Lessons Learned from COVID-19}

$\mathrm{F}$ Tour OAA nutrition program leaders were interviewed for this article, providing updates and a look at the "on the ground" reality of COVID-19's impact on nutrition programs and the older adults they serve. The three agencies and one state department on aging are geographically diverse and serve a wide range of older adults.

Denise Niese is the executive director of the Wood County Committee on Aging, a rural non-profit agency serving all of Wood County, Ohio. In an August 2020 interview, Niese stated that prior to the COVID-19 pandemic, her nutrition program served 6,500 total older adults annually, about 20 percent of the county's older adult population. On March 16, 2020, the agency's eight congregate nutrition sites and adult day care program closed to the general public. All former congregate nutrition clients and adult day care clients became recipients of home-delivered meals overnight, adding strain to Niese's agency; the agency had to create additional meal delivery routes and hire more staff, as all volunteers 70 years of age and older were placed on hiatus because they were high-risk for catching the virus.

In August 2020, Niese's agency was quickly running out of funding to provide nutrition and other services; they had already spent their federal emergency supplemental funding from the CARES Act and Families First Coronavirus Response Act. The agency had been unable to receive Medicaid reimbursement for new home-delivered meals recipients, even if the recipients' meals were formerly funded through Medicaid, because Medicaid funding was contingent on clients receiving onsite services. This situation improved after Congress appropriated further funding.

Jeffrey Klein, the president and chief executive officer of Nevada Senior Services, a large adult day care agency in Las Vegas, Nevada, shared that determination to continue to provide services to older adults. In an August 2020 interview, Klein stated that COVID-19 forced his agency to "rethink and reexamine everything" in the space of aging and caregiving. Klein said in the interview that COVID-19 provided a unique learning opportunity for the aging and disability networks to rethink service delivery on behalf of older adults, who may have to remain homebound for months to come. Ultimately, Klein felt that "the widest lens into the problems that many older adults face is nutrition" and that "if we can solve for nutrition, we can solve for other problems too" 
because nutrition services can provide a pathway for access to treat older adults' broader health and situational concerns.

Tara Ellis is the president and chief executive officer of FeedMore WNY, a food bank and senior nutrition agency serving intergenerational families in four counties in the Buffalo, New York area. In a September 2020 interview, she said that her agency, which was created in December 2019 from the merger of a food bank and a senior nutrition program, felt uniquely situated to leverage all local resources to "meet all of the community where they were at." She said that many of the older adults she served needed multiple nutrition services even prior to the pandemic-congregate nutrition, home-delivered meals, SNAP, and food bank items-and that quite a few of the older adults in her region were part of "grandfamilies" (grandparents caring for grandchildren) who also received services funded by WIC (the federal Special Supplemental Nutrition Program for Women, Infants, and Children administered by the USDA Food and Nutrition Service) through her agency for their grandchildren. Ellis felt that the agencies' merger and variety of services "helped [the Buffalo community] weather the COVID storm," providing a "360-degree view of community need."

Shirley Chao is the director of nutrition for the Massachusetts Executive Office of Elder Affairs in Boston. She shared in an October 2020 discussion that the Office has a long history of identifying nutrition concerns and cre- ating unique programs to meet them. In 2019, they held 82 senior nutrition clinics statewide and conducted nutrition screenings on 800 older adults; 10 percent were found to be at malnutrition risk. In that same year they also screened over 200 homebound seniors and identified 33 percent at malnutrition risk.

Realizing that the COVID-19 pandemic would further increase risk for malnutrition, particularly for homebound older adults, her Office moved quickly to expand and adapt services. They used some federally funded programs to support these surging needs. They used a portion of their Families First Coronavirus Response Act funding to purchase more than half a million frozen and shelf stable meals for those who could not shop for themselves or for those whose drivers quit or needed to be quarantined. Meanwhile, the local nutrition programs distributed boxes of meat to 34,000 seniors in need through the USDA Farmers to Families Food Box program. Some seniors picked up the boxes, but most of them were delivered door to door by the local Councils on Aging or volunteers.

OAA home-delivered meals programs increased 50 percent and congregate meals programs converted to Grab and Go sites at multiple locations, including libraries, senior centers, and parking lots and averaging 2000 meals daily statewide. They also supported many mobile markets delivering food via Senior on the Go buses. One critical group identified early on during the pandemic were caregivers. Massachu- 
setts caregiver specialists saw a significant increase in demand, sometimes with new caregivers seeking resources, and at other times with caregivers who had previously requested only minimal help suddenly reaching out for weekly, ongoing support.

During the pandemic, social media became a good vehicle to reach seniors. In March 2020, the state of Massachusetts launched a statewide "\#doacovidcheck" social media campaign that had more than 10,000 views. The state has a \#covid19MA website, where people can access all food assistance resources in Massachusetts. In September 2020, they launched the social media campaign "Be a Nutrition Neighbor" during Malnutrition Awareness Week, ${ }^{\mathrm{TM}}$ focusing on malnutrition awareness and prevention. Thirty-five agencies and entities posted about this on their social media sites.

The four interviews tell a similar story; nationwide, community and governmental agencies had to quickly adapt to meet the needs of the older adults they serve, often through changing their service delivery models entirely. With in-person congregate meals no longer an option, programs became creative to decrease older adults' social isolation (a risk factor for malnutrition); for example, Niese's agency hosted virtual "congregate" meals and nutrition education via the Zoom videoconferencing platform. Some Massachusetts community nutrition programs have incorporated video recordings, including converting daily activities to Zoom sessions, recording the sessions, and sending those videos to the cable access networks and Councils on Aging. All three of the community program leaders interviewed for this article had their agencies' staff make telephone reassurance calls to their clients and conduct wellness checks when delivering meals to clients' homes.

As agencies are implementing plans to open congregate programs, they are now considering how to best "re-engage" older adults. While some OAA participants are eager to return to congregate meals, others are expressing hesitancies to moving back to "in-person" meals programs. Thus, programs may need to consider how to diversity their offerings to continue to meet the needs of local communities.

\section{Future Nutrition Policy Directions}

7 here are various steps that policymakers can take now to ensure that older adults are able to access adequate nutrition, both as the pandemic continues and after the pandemic ends.

As the pandemic winds down, more funding is desperately needed for community nutrition services to continue to meet the needs of newly-enrolled older adult program participants.. Funding to meet demand has long been an issue with OAA nutrition programs; in a brief published by AARP in 2019, the authors found that "adjusting for inflation, not only have total OAA appropriations over the past 18 years [federal fiscal years 2001-2019] 
failed to keep pace with [older adult] population growth, they actually fell by 16 percent" (Ujvari et al., 2019). This problem is exacerbated in the short term by the pandemic driving high demand for nutrition programs and over the long term by the continued increase in the size of the older adult population.

For both the OAA nutrition program and SNAP, nutrition advocates are worried about a benefits "cliff," where older adults who have become accustomed to-and are still very much in need of-receiving new community services and extended benefits may no longer be able to access them, whether because community nutrition program funding has run out or the extended benefits period has expired. Long-term policies need to be enacted to prevent this from happening, possibly in the form of an overall increase in OAA nutrition program appropriations levels and in boosts to the SNAP maximum and minimum benefits based on an adequate food plan. The 2020 OAA reauthorization significantly increased authorization levels for "regular" appropriations; Congress should meet and exceed those authorized levels when the pandemic ends (Supporting Older Americans Act, 2020).

Further, to ensure access to SNAP, building SNAP partnerships with area agencies on aging, AARP chapters, Meals on Wheels programs, and other community organizations that can help reach new groups of older adults and cross-promote programs is one of the most effective ways for states to connect more older adults to SNAP, reduce hunger, strengthen SNAP services, and maximize federal reimbursement.

Debate continues among advocates over whether the flexibilities extended to OAA nutrition programs (DRI waivers, transfer authority limit waivers) should be continued post-pandemic. One issue that has been raised is that without assurance of healthful diets, these community meals would not be expected to reduce food insecurity and malnutrition or provide the benefits for the older population that studies and evaluations have demonstrated. Regardless of whether these flexibilities are continued, one clear lesson is that Congress can and should continue to take steps to ensure that vital federal nutrition programs such as the OAA are responsive to emergency needs, whether in this pandemic or in future crises.

Passage of legislation to address gaps in older adult nutrition care and food security is also key. The 2020 OAA reauthorization for the first time added "reducing malnutrition" to the purposes of the nutrition program and included malnutrition screening as part of the OAA's nutrition screening requirements (Supporting Older Americans Act, 2020). Some community nutrition programs had already been performing screenings for malnutrition, and this addition should prompt many more programs to provide this type of screening. During a future OAA reauthorization, it would be important to add requirements to screen recipients for food insecurity as well. 
Several other relevant nutrition care bills were introduced in mid-2020; however, none became law. One bill, the Medical Nutrition Therapy Act of 2020, would have expanded Medicare Part B coverage of medical nutrition therapy to chronic conditions other than the three currently covered (diabetes, kidney disease, and kidney transplants), including malnutrition, prediabetes, obesity, hypertension, dyslipidemia, eating disorders, cancer, celiac disease, HIV/AIDS and any other disease or condition causing unintentional weight loss. This bill has been reintroduced in the $117^{\text {th }}$ Congress. Another bill, the Medically Tailored Home-Delivered Meals Demonstration Pilot Act of 2020, would have established a demonstration pilot program to provide medically tailored, home-delivered meals to recently hospitalized Medicare enrollees with nutrition-related conditions such as congestive heart failure, diabetes, and kidney disease.

Policy provisions that allow continued access to telemedicine services for Medicare beneficiaries, regardless of location, beyond the COVID-19 pandemic are also vital to ensuring efficient and effective ongoing patient care for malnutrition. While both audio and visual contact is the ideal, many older adults do not have access to the technology necessary to ensure the visual component. CMS should permanently allow nutrition screening and other healthcare services to be provided and covered by Medicare via telephone contact alone if that is all that is available to the patient.

\section{Conclusions}

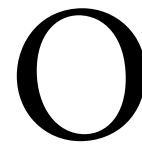
lder adults are at higher risk of malnutrition and of developing severe complications from COVID-19. Both conditions also share common risk factors that may be amplified by the virus itself as well as social impacts related to the pandemic, including food insecurity. Identification of risk for malnutrition and food insecurity are important for quality care because of their influence on healthy aging and medical outcomes. The implementation of nutrition-focused quality improvement programs, particularly those targeting transitions of care, may be beneficial to help risk screening become part of routine medical care and care provided during pandemics.

Interventions for malnutrition and food insecurity include the federal food and nutrition programs like SNAP and OAA programs. Clinicians and health systems can play critical roles in helping reframe food assistance as a benefit that supports health and independence and in integrating timely referrals to community-based programs into their medical discharge and care plans. In addition, they can join with other stakeholders to advocate for better funding for these programs. Prior to the COVID-19 pandemic, community-based programs were already chronically underfunded and many had waiting lists for those seeking services. The significant surge in requests during the pandemic more than doubled the number of meals being provided which made an already bad financial situation even worse for these essential programs. 
In summary, the nutritionrelated policies necessary for supporting older adults in the community during a pandemic are the same as those needed to help ensure healthy aging at any point in time, only magnified. Before, during, and after the pandemic, a robust national nutrition policy should include having appropriate systems in place to quickly identify risk for malnutrition and food insecurity and supporting adequate nutrition interventions through fully funding, strengthening, and improving access to food and nutrition programs and community-based meals providers (Box 2). These are the fundamentals for safeguarding that no older adult suffers from malnutrition, is left hungry, or is unserved at their time of greatest need.

Box 2: Key takeaways for advocates

1) More funding is needed for community nutrition services to continue to meet the needs of newly-enrolled older adult program participants.

2) Long-term policy should include an overall increase in OAA nutrition program appropriations levels and in boosts to the SNAP maximum and minimum benefits based on an adequate food plan.

3) States and advocates should build SNAP partnerships with area agencies on aging, AARP chapters, Meals on Wheels programs, and other community organizations.

4) Passage of legislation to address gaps in older adult nutrition care and food security is also key.

5) Policy provisions should allow continued access to telemedicine services for Medicare beneficiaries, regardless of location, beyond the COVID-19 pandemic.

6) The implementation of nutrition-focused quality improvement programs, particularly those targeting transitions of care, may be beneficial to help malnutrition and food insecurity risk screening become part of routine medical care and care provided during pandemics.

\section{References}

Academy of Nutrition and Dietetics. (n.d.). Electronic clinical quality measures (eCQMs).https://www.eatrightpro.org/practice/quality-management/ quality-improvement/malnutrition-quality-improvement-initiative

Administration for Community Living. (2020). Nutrition services. https://acl.gov/ programs/health-wellness/nutrition-services

Administration for Community Living. (2019). FY 2016 report to Congress: Older Americans Act. https://acl.gov/sites/default/files/about-acl/2019-02/FY20 16_OAA\%20Report\%20to\%20Congress.pdf 
Afulani, P., Herman, D., Coleman-Jensen, A., Harrison, G. G. (2015). Food insecurity and health outcomes among older adults: The role of cost-related medication underuse. Journal of Nutrition in Gerontology and Geriatrics, 34(3), 319-342. https://doi:10.1080/21551197.2015.1054575

Aguila, E. J. T., Cua, I. H. Y., Dumagpi, J. E. L., Francisco, C. P. D., Raymundo, N. T. V., Sy-Janairo, M. L. L., Cabral-Prodigalidad, P. A. I., Lontok, M. A. D. C. (2020). COVID-19 and its effects on the digestive system and endoscopy practice. JGH Open, 4(3), 324-331. https://dx.doi.org/10.1002/ Fjgh3.12358

Avalere Health. (2018). Dialogue proceedings: advancing patient-centered malnutrition care transitions. https://www.defeatmalnutrition.today/sites/default /files/documents/Dialogue\%20Proceedings_Malnutrition\%20Transitions\%20of\%20Care_20180726.pdf

Barker, L. A., Gout, B. S., Crowe, T. C. (2011). Hospital malnutrition: prevalence, identification and impact on patients and the healthcare system. International Journal of Environmental Research and Public Health, 8(2), 514-527.

Barrett, M. L., Bailey, M. K., Owens, P. L. (2018). Non-maternal and non-neonatal inpatient stays in the United States involving malnutrition, 2016. U.S. Department of Health and Human Services, Agency for Healthcare Research and Quality. http://www.hcupus.ahrq.gov/reports.jsp

Bernstein, M. \& Munoz, N. (2012). Position of the Academy of Nutrition and Dietetics: food and nutrition for older adults: promoting health and wellness. Journal of the Academy of Nutrition and Dietetics, 112(8), 1255-1277.

Bhargava, V., Lee, J. S. (2016). Food insecurity and health care utilization among older adults in the United States. Journal of Nutrition in Gerontology and Geriatrics, 35(3), 177-92. https://doi.org/10.1080/21551197.2016.1200334

Briguglio, M., Pregliasco, F. E., Lombardi, G., Perazzo, P., Banfi, G. (2020). The malnutrition status of the host as a virulence factor for new Coronavirus SARS-CoV-2. Frontiers in Medicine, 7:146. https://doi.org/10.3389/fmed.20 20.00146

Brugliera, L., Spina, A., Castellazzi, P., Cimino, P., Arcuri, P., Negro, A., Houdayer, E., Alemanno, F., Giordani, A., Mortini, P., Iannaccone, S. (2020). Nutritional management of COVID-19 patients in a rehabilitation unit. European Journal of Clinical Nutrition, 74, 860-863. https://doi.org/10.1038/ s41430-020-0664-X

Campbell, A. D., Godfryd, A., Buys, D. R., Locher, J. L. (2015). Does participation in home-delivered meals programs improve outcomes for older adults? 
Results of a systematic review. Journal of Nutrition in Gerontology and Geriatrics, 34(2), 124-167.

Center on Budget and Policy Priorities. (2020). USDA, states must act swiftly to deliver food assistance allowed by Families First Act. https://www.cbpp.org/ research/food-assistance/usda-states-must-act-swiftly-to-deliver-food-assistance-allowed-by-families

Centers for Disease Control and Prevention. (2020). Coronavirus disease 2019 (COVID-19), People with certain medical conditions. https://www.cdc.gov/ coronavirus/2019-ncov/need-extra-precautions/people-with-medicalconditions.html

Centers for Medicare \& Medicaid Services (CMS). (2020). Trump Administration drives telehealth services in Medicaid and Medicare. https://www.cms.gov/ newsroom/press-releases/trump-administration-drives-telehealth-services-medicaid-and-medicare

Centers for Medicare \& Medicaid Services (CMS). (2019). Announcement of Calendar Year (CY) 2020 Medicare Advantage capitation rates and Medicare Advantage and Part D payment policies and final call letter. https://www. cms.gov/Medicare/Health-Plans/MedicareAdvtgSpecRateStats/Down loads/Announcement2020.pdf

Colello, K. (2020a). Older Americans Act: Nutrition services program. Congressional Research Service. https://crsreports.congress.gov/product/pdf/IF/ IF10633

Colello, K. (2020b). Senior nutrition programs' response to COVID-19. Congressional Research Service. https://crsreports.congress.gov/product/pdf/IN/ IN11266

Coronavirus Aid, Recovery, and Economic Security (CARES) Act, Pub. L. No. 116136 (2020). https://www.congress.gov/bill/116th-congress/house-bill/748

Dabrowska, A. (2017). Malnutrition in older adults. Congressional Research Service. https://www.defeatmalnutrition.today/sites/default/files/documents/ CRS_Memo_Malnutrition_in_Older_Adults.pdf

Defeat Malnutrition Today. (n.d.). About us. https://www.defeatmalnutrition.today /about

Dwyer, J. T., Gahche, J. J., Weiler, M., Arensberg, M. B. (2020). Screening community-living older adults for protein energy malnutrition and frailty: update and next steps. Journal of Community Health, 45, 640-660. https://doi. org/10.1007/s10900-019-00739-1 
Eggersdorfer, M., Akobundu, U., Bailey, R. L., Shlisky, J., Beaudreault, A. R., Bergeron, G., Blancato, R. B., Blumberg, J. B., Bourassa, M. W., Gomes, F., Jensen, G., Johnson, M. A., Mackay, D., Marshall, K., Meydani, S. N., \& Tucker, K. L. (2018). Hidden hunger: solutions for America's aging populations. Nutrients, 10(9), e1210.

Feeding America. (2020). Senior hunger in the United States. https://www.feedingamerica.org/research/senior-hunger-research/senior

Feeding America \& National Foundation to End Senior Hunger. (2014). Spotlight on senior health: Adverse health outcomes of food insecure older Americans. https://www.feedingamerica.org/sites/default/files/research/senior-hun ger-research/or-spotlight-on-senior-health-executive-summary.pdf

Ferrara, F., De Rosa, F., Vitiello, A. (2020). The Central Role of Clinical Nutrition in COVID-19 Patients During and After Hospitalization in Intensive Care Unit. SN Comprehensive Clinical Medicine, 1-5. Advance online publication. https://doi.org/10.1007/s42399-020-00410-0

Food Research \& Action Center. (2020). Helping older adults struggling against hunger access food in the age of COVID-19. https://frac.org/wp-content/ uploads/FRAC-Brief-Helping-Older-Adults-Struggling-Against-HungerAccess-Food-in-the-Age-of-COVID-19.pdf

Food Research \& Action Center. (2019). Hunger is a health issue for older adults: food security, health, and the federal nutrition programs. https://frac.org/ wp-content/uploads/hunger-is-a-health-issue-for-older-adults-1.pdf

Food Research \& Action Center. (2017). SNAP and public health: the role of the Supplemental Nutrition Assistance Program in improving the health and well-being of Americans. https://frac.org/research/resource-library/ snap-public-health-role-supplemental-nutrition-assistance-program-im proving-health-well\%E2\%80\%90being-americans.

Food Research \& Action Center \& AARP Foundation. (2018). Screen \& intervene: addressing food insecurity among older adults. https://frac.learnercommunity.com/account/login/secure? returnUrl=\%2Factivity\%2Fenrollment\%2Fautoenroll\%3FproductId\%3Daf4785d7-638b-41a2-bc49-3a928cb9c951\%26sectionId\%3Df604dc96-4c56-4d8b-a787-865377b0c8d1

Food Research \& Action Center, Schanzenbach, D. (2020). Not enough to eat: COVID-19 deepens America's hunger crisis. https://frac.org/wp-content/ uploads/Not-Enough-to-Eat_Hunger-and-COVID.pdf

Further Consolidated Appropriations Act, 2020, Pub. L. No. 116-94 (2020). https:// www.congress.gov/bill/116th-congress/house-bill/1865/text 
Garcia, S. P., Haddix, A., Barnett, K. (2018). Incremental health care costs associated with food insecurity and chronic conditions. U.S. Department of Health and Human Services, Centers for Disease Control and Prevention. https:// www.cdc.gov/pcd/issues/2018/18_0058.htm

Gerteis, J., Izrael, D., Deitz, D., LeRoy, L., Ricciardi, R., Miller, T., Basu, J. (2014). Multiple chronic conditions chartbook. U.S. Department of Health and Human Services, Agency for Healthcare Research and Quality. https://www. ahrq.gov/sites/default/files/wysiwyg/professionals/prevention-chroniccare/decision/mcc/mccchartbook.pdf

Goger, A. (2020, March 16). For millions of low-income seniors, coronavirus is a food-security issue. The Avenue. https://www.brookings.edu/blog/the-av enue/2020/03/16/for-millions-of-low-income-seniors-coronavirus-is-afood-security-issue/

Gundersen, C., Englehard, E. E., Crumbaugh, A. S., Seligman, H. K. (2017). Brief assessment of food insecurity accurately identifies high-risk US adults. Public Health Nutrition, 29(8), 1367-1371.

Gundersen, C., \& Ziliak, J. (2017). The health consequences of senior hunger in the United States: evidence from the 1999-2014 NHANES. https://www.feed ingamerica.org/sites/default/files/research/senior-hunger-research/se nior-health-consequences-2014.pdf

Handu, D., Moloney, L., Rozga, M., Cheng, F. (2020). Malnutrition care during the COVID-19 pandemic: considerations for registered dietitian nutritionists. Journal of the Academy of Nutrition and Dietetics. https://doi.org/10.1016/j. jand.2020.05.012

Heiman, H. J., \& Artiga, S. (2018). Beyond health care: The role of social determinants in promoting health and health equity. https://www.kff.org/racial-equityand-health-policy/issue-brief/beyond-health-care-the-role-ofsocial-determinants-in-promoting-health-and-health-equity/ Hernandez, J. L., Nan, D., Fernandez-Ayala, M., Garcia-Unzueta, M., Hernandez-Hernandez, M. A., Lopez-Hoyos, M., Cacho, P. M., Olmos, J. M., Gutierrez-Cuadra, M., Ruiz-Cubilllan, J. J., Crespo, J., Martinez-Taboada, V. M. (2020). Vitamin D status in hospitalized patients with SARS-CoV-2 infection. Journal of Clinical Endocrinology and Metabolism. https://doi. org/10.1210/clinem/dgaa733

Ishida, Y., Maeda, K., Nonogaki, T., et al. (2020). Malnutrition at admission predicts in-hospital falls in hospitalized older adults. Nutrients, 12(2): 541.

Izawa, S., Kuzuya, M., Okada, K., et al. (2006). The nutritional status of frail elderly with care needs according to the mini nutritional assessment. Journal of 
Clinical Nutrition, 25(6), 962-967.

Jih, J., Stijacic-Cenzer, I., Seligman, H. K., Boscardin, W. J., Nguyen, T. T., Ritchie, C. S. (2018). Chronic disease burden predicts food insecurity among older adults. Public Health Nutrition, 21(9), 1737-1742.

Jin, Y.-H., Cai, L., Cheng, Z.-S., Cheng, H., Deng, T., et al. (2020). A rapid advice guideline for the diagnosis and treatment of 2019 novel coronavirus (2019$\mathrm{nCoV}$ ) infected pneumonia (standard version). Military Medical Research, 7(4). https://doi.org/10.1186/s40779-020-0233-6

Kaiser, M. J., Bauer, J. M., Ramsch, C., et al. (2010). Frequency of malnutrition in older adults: a multinational perspective using the mini nutritional assessment. Journal of the American Geriatric Society, 58(9), 1734-1738.

Lanctin, D. P., Merced-Nieves, F., Mallett, R. N., Arensberg, M. B., Guenter, P., Sulo, S., Platts-Mills, T. F. (2019). Prevalence and economic burden of malnutrition diagnosis among patients presenting to United States emergency departments. Academic Emergency Medicine. https://doi.org/10.1111/ acem. 13887

Laviano, A., Koverech, A., Zanetti, M. (2020). Nutrition support in the time of SARS-CoV-2 (COVID-19). Journal of Nutrition, 74, 1108-34.

Lee, J. H., Hutzler, L. H., Shulman, B. S., Karia, R. J., Egol, K. A. (2015). Does risk for malnutrition in patients presenting with fractures predict lower quality measures? Journal of Orthopedic Trauma, 29(8), 373-378.

Lee, J. S., \& Frongillo, E. A. Jr. (2001). Nutritional and health consequences are associated with food insecurity among U.S. elderly persons. Journal of $\mathrm{Nu}$ trition, 131(5), 1503-1509.

Li, T., Zhang, Y., Gong, C., Wang, J., Liu, B., Shi, L., Duan, J. (2020). Prevalence of malnutrition and analysis of related factors in elderly patients with COVID-19 in Wuhan, China. European Journal of Clinical Nutrition, 74, 871-875. https://doi.org/1038/s41430-020-0642-3

Lyles, C. R., Schafer, A. L., Seligman, H. K. (2014). Income, food insecurity, and osteoporosis among older adults in the 2007-2008 National Health and Nutrition Examination Survey (NHANES). Journal of Health Care for the Poor and Underserved, 25(4), 1530-1541.

Malnutrition Quality Improvement Initiative. (2020). The MQii toolkit. http://mal nutritionquality.org/mqii-toolkit.html

Malnutrition Quality Improvement Initiative. (2018). Malnutrition quality improvement initiative toolkit, second edition. http://malnutritionquality.org/ static/pdf/select-your-quality-improvement-focus.pdf 
Meals on Wheels America. (2020). New survey data: demand on Meals on Wheels national network swells and wait lists grow due to COVID-19 pandemic. https://www.mealsonwheelsamerica.org/learn-more/national/pressroom/news/2020/05/07/new-survey-data-demand-on-meals-on-wheelsnational-network-swells-and-wait-lists-grow-due-to-covid-19-pandemic

Medical Nutrition Therapy Act of 2020, H.R. 6971, 116th Cong. (2020). https:// www.congress.gov/bill/116th-congress/house-bill/6971

Medically Tailored Home-Delivered Meals Demonstration Pilot Act of 2020, H.R. 6774, 116th Cong. (2020). https://www.congress.gov/bill/116th-congress/ house-bill/6774

Meltzer, D. O., Best, T. J., Zhang, H. (2020). Association of vitamin D status and other clinical characteristics with COVID-19 test results. JAMA Network Open, 3(9), e2019722. https://doi.org/10.1001/jamanetworkopen.2020.19722

Montoya, M. F., Hite, A. W., Rohrbeck, P., Bawa, B., Akinwolemiwa, O. O., Benson, A. M., Luna-Hollen, M., \& Reyes-Ortiz, C. A. (2011). Quality of diet related to food insecurity and food stamps use among older people. Ageing Research, 3, e3.

Nalbandian, A., Sehgal, K., Gupta, A., Madhavan, M.V., McGroder, Cl, Stevens, J.S., et al. (2021). Post-acute COVID-19 syndrome. Nature Medicine, 27, 601-615. https://doi.org/10.1038/s41591-021-01283-Z

Naja, F. \& Hamedeh, R. (2020). Nutrition amid the COVID-19 pandemic: a multi-level framework for action. European Journal of Clinical Nutrition, April 2020, 1-5. https://doi.org/10.1038/s41430-020-0634-3

Nakeshbandi, M., Maini, R., Daniel, P., Rosengarten, S., Parmar, P., Wilson, C., Kim, J. M., Oommen, A., Mecklenburg, M., Salvani, J., Joseph, M. A., Brietman, I. (2020). The impact of obesity on COVID-19 complications: a retrospective cohort study. International Journal of Obesity, 44, 1832-1837.

National Association of Nutrition and Aging Services Programs (NANASP). (2020, May 1). Tivity Health, $n 4 a$ and NANASP partner to provide senior nutrition during COVID-19 crisis. http://nanasp.org/node/166

Nettle, D., Andrews, C., Bateson, M. (2017). Food insecurity as a driver of obesity in humans: the insurance hypothesis. Behavioral and Brain Sciences, 40, e105.

Older Americans Act, 42 U.S.C. $\$ 3001$ et seq. (2020). https://www.govinfo.gov/ app/details/USCODE-2010-title42/USCODE-2010-title42-chap35-subchapI-sec3001 
Pereira, G. F., Bulik, C. M., Weaver, M. A., et al. (2015). Malnutrition among cognitively intact, noncritically ill older adults in the emergency department. Annals of Emergency Medicine, 65, 85-91.

Pooler, J. A., Hartline-Grafton, H., DeBor, M., Sudore, R. L., Seligman, H. K. (2019). Food insecurity: a key social determinant of health for older adults. Journal of the American Geriatrics Society, 67, 421-424.

Portela-Parra, E. T., \& Leung, C. W. (2019). Food insecurity is associated with lower cognitive functioning in a national sample of older adults. Journal of Nutrition, 149(10), 1812-1817.

Redmond, M. L., Dong, F., Goetz, J., Jacobson, L. T., Collins, T. C. (2016). Food insecurity and peripheral arterial disease in older adult populations. Journal of Nutrition, Health, and Aging, 20(10), 989-995.

Riley, K., Sulo, S., Dabbous, F., Partridge, J., Kozmic, S., Landow, W., et al. (2020). Reducing hospitalizations and costs: a home health nutrition-focused quality improvement program. Journal of Parenteral and Enteral Nutrition, 44(1), 58-68.

Russell, C. (2019, November). Addressing malnutrition in older adults during care transitions, current state of assessment. https://www.mealsonwheelsamerica. org/docs/default-source/research/nourishing-transitions/addressing-mal nutrition-web-final.pdf

Schanzenbach, D. \& Pitts, A. (2020, September 9). Food insecurity in the Census Household Pulse Survey data tables. IPR Rapid Research Report. https:// www.ipr.northwestern.edu/documents/reports/ipr-rapid-research-re ports-pulse-hh-data-1-june-2020.pdf

Sharma, Y., Miller, M., Kaambwa, B., et al. (2017). Malnutrition and its association with readmission and death within 7 days and 8-180 days post-discharge in older patients: a prospective observational study. BMJ Open, 2017(7).

Skopec, L., Ramos, C., Aarons, J. (2019, September) U.S. health reform-monitory and impact, are Medicare Advantage plans using new supplemental benefit flexibility to address enrollees' health-related social needs? The Urban Institute. https://www.urban.org/sites/default/files/publication/101067/sdh_ medicare_advantage.pdf

Soeters, P. B. \& Schols, A. M. (2009). Advances in understanding and assessing malnutrition. Current Opinions in Clinical Nutrition and Metabolic Care, 12(5), 487-494.

Strickhouser, S., Wright, J. D., Donley, A. M. (2014, September). Food insecurity among older adults, a report submitted to AARP Foundation. https://www. 
aarp.org/content/dam/aarp/aarp_foundation/2015-PDFs/AF-Food-Inse curity-2015Update-Final-Report.pdf

Sulo, S., Feldstein, J., Partridge, J., Schwander, B., Sriram, K., Summerfelt, W. T. (2017). Budget impact of a comprehensive nutrition-focused quality improvement program for malnourished hospital patients. American Health \& Drug Benefits, 10(5), 262-270.

Sulo, S., Kozmic, S., Summerfelt, W. T., Partridge, J., Hegazi, R., Sriram, K. (2017, May 1-4). Nutrition based interventions decrease readmission rates and length of stay among malnourished hospitalized adult patients with cardiovascular; oncological, and gastrointestinal diagnoses [Conference session]. Hospital Medicine 2017, Las Vegas, Nevada, United States.

Supporting Older Americans Act of 2020, Pub. L. No. 116-131 (2020). https:// www.congress.gov/bill/116th-congress/house-bill/4334/text

Szanton, S. L., Samuel, L. J., Cahill, R., Zielinskie, G., Wolff, J. L., Thorpe, R. J. Jr., $\&$ Betley, C. (2017). Food assistance is associated with decreased nursing home admissions for Maryland's dually eligible older adults. BMC Geriatrics, 17(1), 162.

Tappenden, K. A., Quatrara, B., Parkhurst, M. L., Malone, A. M., Fanjiang, G., Ziegler, T. R. (2013). Critical role of nutrition in improving quality of care: an interdisciplinary call to action to address adult hospital malnutrition. Journal of the Academy of Nutrition and Dietetics, 113(9), 1219-1237.

The Malnutrition Quality Collaborative. (2020). National blueprint: achieving quality malnutrition care for older adults, 2020 update. http://defeatmalnu trition.today/blueprint

Thomas, K. S. (2015). Outcomes matter: the need for improved data collection and measurement in our nation's home delivered meals programs. Journal of Nutrition in Gerontology and Geriatrics, 34(2), 85-89.

Ujvari, K., Fox-Grage, W., Houser, A. (2019). AARP Public Policy Institute: Spotlight: Older Americans Act. https://www.aarp.org/content/dam/aarp/ ppi/2019/02/older-americans-act.pdf

United Nations. (n.d.). Sustainable development goals, goal 2: Zero hunger. https:// www.un.org/sustainabledevelopment/hunger/

U.S. Department of Agriculture (USDA). (2020a). COVID-19 waivers by state. https://www.fns.usda.gov/disaster/pandemic/covid-19/snap-waivers-flex ibilities

U.S. Department of Agriculture. (2020b). U.S. Department of Agriculture launch- 
es the online purchasing pilot. https://www.fns.usda.gov/snap/online-purchasing-pilot

U.S. Department of Agriculture. (2019). Definitions of food security. https://www. ers.usda.gov/topics/foodnutrition-assistance/food-security-in-the-us/ definitions-of-food-security/

U.S. Department of Health and Human Services, Office of Disease Prevention and Health Promotion (HHS ODPHP). (2020a). Healthy People 2030: Social determinants of health. https://health.gov/healthypeople/objectives-and-da ta/social-determinants-health.

U.S. Department of Health and Human Services, Office of Disease Prevention and Health Promotion (HHS ODPHP). (2020b). Healthy People 203-: Economic Stability. https:/health.gov/healthypeople/objectives-and-data/ browse-objectives/economic-stability

U.S. Government Accountability Office. (2019, November). Nutrition assistance programs: agencies could do more to help address the nutritional needs of older adults. https://www.gao.gov/assets/710/702788.pdf

Vivanti, A., Isenring, E., Baumann, S., et al. (2015). Emergency department malnutrition screening and support model improves outcomes in a pilot randomized controlled trial. Emergency Medicine Journal, 32, 180-183.

Wells, J. L. \& Dumbrell, A. C. (2006). Nutrition and aging: assessment and treatment of compromised nutritional status in frail elderly patients. Clinical Interventions in Aging, 1(1), 67-79.

Wolfson, J. A. \& Leung, C.W. (2020). Food insecurity and COVID-19: disparities in early effects for US adults. Nutrients, 12(6), 1648.

World Bank. (2020, 7 August). Brief: food security and COVID-19. https://www. worldbank.org/en/topic/agriculture/brief/food-security-and-covid-19

World Health Organization. (n.d.). Nutrition for older persons. https://www.who. int/nutrition/topics/ageing/en/indexl.html

World Health Organization. (2020). 2020 Global nutrition report: Action on equity to end malnutrition. https:/globalnutritionreport.org/reports/2020-globalnutrition-report/

Zellner, H. K., Moss, O. A., Peterson, S. J., et al. (2019). Differences in respiratory muscle strength measures in well-nourished and malnourished hospitalized patients. Journal of the Academy of Nutrition and Dietetics, 119(5), 831-839.

Zhang, L., Liu, Y. (2020). Potential interventions for novel coronavirus in China: a systematic review. Journal of Medical Virology, 92, 479-490. 
Nutrition-Related Policy Fundamentals for Supporting Older Adults in the Community during a Pandemic: Lessons from COVID-19

\section{Appendix 1}
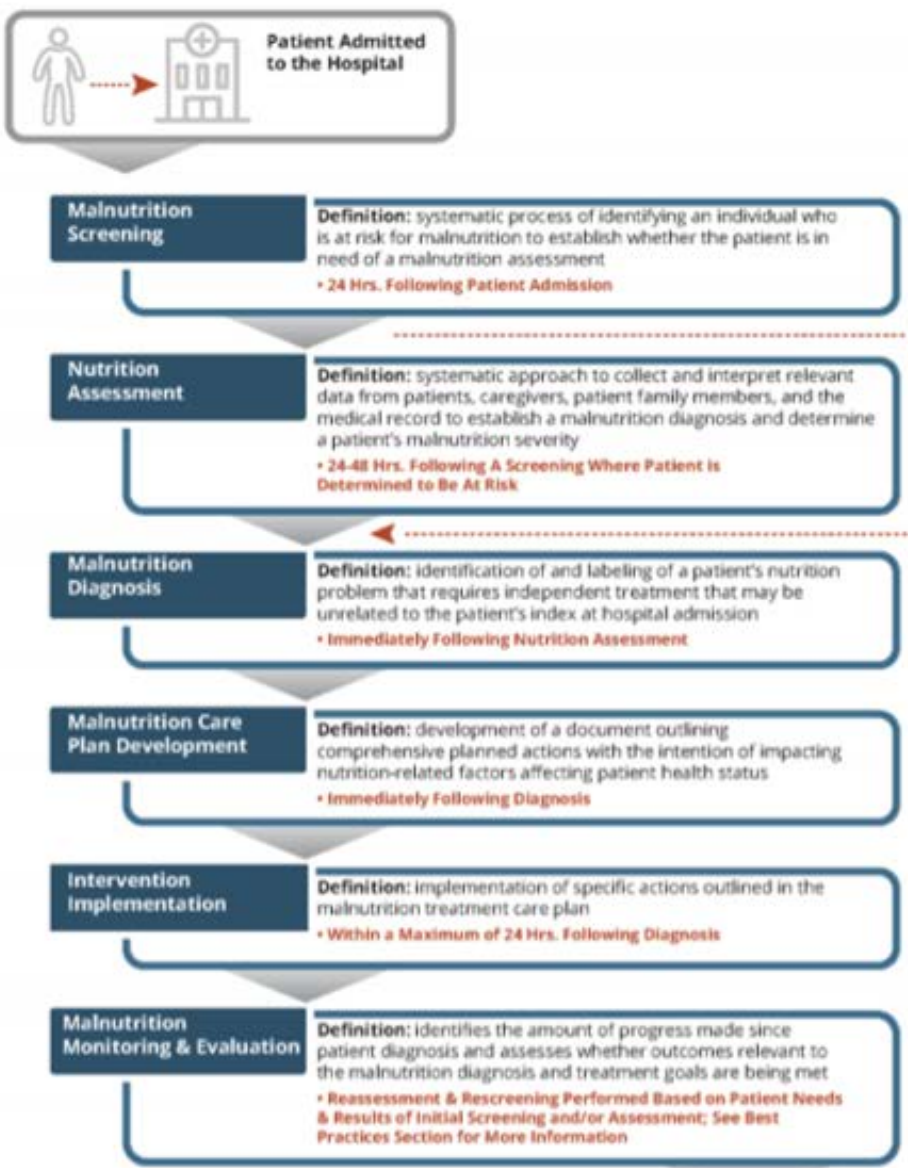

Initiate Dietitian Consult and Malnutrition-Risk Diet Order for At-Risk Patients

- intervene immediately for at-risk patients with food and/or oral rutritional supplement per malrutrition-risk protocol to accelerate treatment uniess contraindicated

- Conduct nutrition assessment as soon as possible

- Following assessment, any active malnutrition-risk diet order should be reevaluated

\section{Discharge Planning}

Definition: documentation of mainutrition diagnosis, status, and orders in discharge plap

- 24 Hirs. Proor to Hespital Discharge for Patients Previeusly Assessed to be At hisk or Maineurished 
Journal of Elder Policy

\section{Appendix 2}

Table 1: Key Characteristics of Federal Nutrition Assistance Programs Serving Older Adults, by Agency

Dollars in Millions

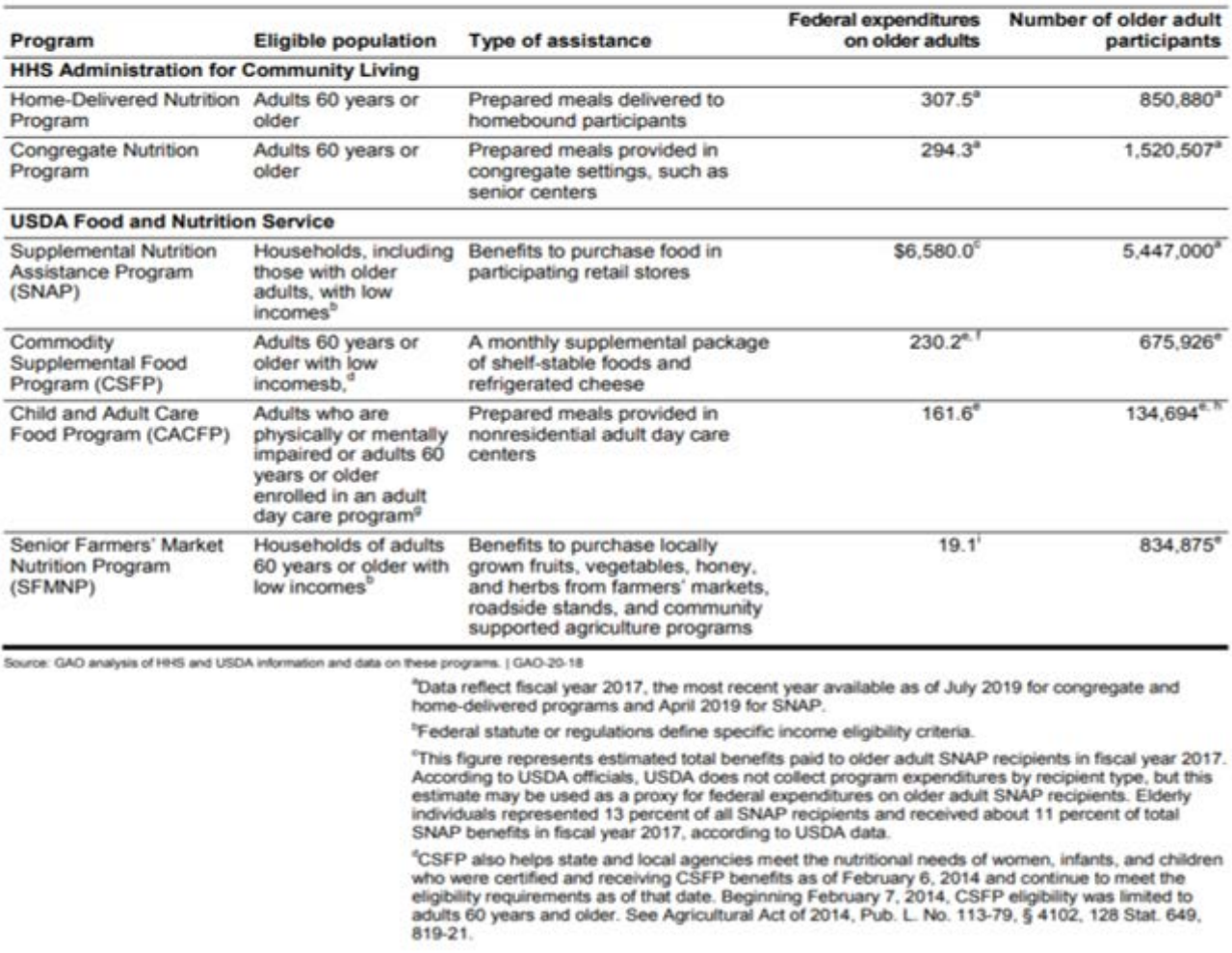


Nutrition-Related Policy Fundamentals for Supporting Older Adults in the Community during a Pandemic: Lessons from COVID-19

\section{APPENDix 3}

\section{Goals and Strategies of the National Blueprint: Achieving Quality Malnutrition Care for Older Adults}

\section{Goal 1 Improve Quality of Malnutrition Care Practices}

\section{Strategies}

1. Establish Science-Based National, State, and Local Goals for Quality Malnutrition Care

2. Identify Quality Gaps in Malnutrition Care

3. Establish and Adopt Quality Malnutrition Care Standards

4. Ensure High-Quality Transitions of Care

\section{Goal 2 Improve Access to High-Quality Malnutrition Care and Nutrition Services}

\section{Strategies}

1. Integrate Quality Malnutrition Care in Payment and Delivery Models and Quality Incentive Programs

2. Reduce Barriers to Quality Malnutrition Care

3. Strengthen Nutrition Professional Workforce

\section{Goal 3 Generate Clinical Research on Malnutrition Quality of Care}

\section{Strategies}

1. Evaluate Effectiveness and Impact of Best Practices on Patient Outcomes and Clinical Practice

2. Identify and Fill Research Gaps by Conducting and Disseminating Relevant Research

3. Track Clinically Relevant Nutritional Health Data

\section{Goal 4 Advance Public Health Efforts to Improve Malnutrition Quality of Care}

\section{Strategies}

1. Train Healthcare Providers, Social Services, and Administrators on Quality Malnutrition Care

2. Educate Older Adults and Caregivers on Malnutrition Impact, Prevention, Treatment, and Available Resources

3. Educate and Raise Visibility with National, State, and Local Policymakers

4. Integrate Malnutrition Care Goals in National, State, and Local Population Health Management Strategies

5. Allocate Education and Financial Resources to HHS- and USDA-Administered Food and Nutrition Programs 
Journal of Elder Policy

\section{APpendix 4}

\begin{tabular}{|c|c|c|}
\hline Measure 11 & $\begin{array}{l}\text { Measure Title: Completion of a Screening } \\
\text { for Malnutrition Risk and Referral to a } \\
\text { Registered Dietitian Nutritionist (RDN) for } \\
\text { At-Risk Patients }\end{array}$ & $\begin{array}{l}\text { Measure Title: Completion of a Screening } \\
\text { for Malnutrition Risk and Referral to a RDN } \\
\text { for At-Risk Patients }\end{array}$ \\
\hline Measure 12 & $\begin{array}{l}\text { Measure Title: Assessment of } \\
\text { Nutritionally At-Risk Patients for } \\
\text { Malinutrition and Development of Nutrition } \\
\text { Recommendations/ Interventions by a RDN }\end{array}$ & $\begin{array}{l}\text { Measure Title: Assessment of Nutritionally } \\
\text { At-Risk Patients for Malnutrition and } \\
\text { Development of Nutrition Recommendations/ } \\
\text { Interventions by a RDN }\end{array}$ \\
\hline Measure : 3 & $\begin{array}{l}\text { Measure Title: Appropriate Documentation } \\
\text { of Malnutrition Diagnosis }\end{array}$ & $\begin{array}{l}\text { Measure Title: Obtaining Preoperative } \\
\text { Nutritional Pecommendations from a RDN } \\
\text { in Nutritionally At-Risk Surgical Patients }\end{array}$ \\
\hline Measure 14 & $\begin{array}{l}\text { Measure Title: Nutritional Care Plan } \\
\text { Communicated to Post-Discharge Provider }\end{array}$ & $\begin{array}{l}\text { Measure Title: Appropriate Documentation } \\
\text { of Malnutrition Dlagnosis }\end{array}$ \\
\hline Key & Measures Approved for MIPS Reporting & $\begin{array}{l}\text { Measures Adopted by Registry, Not Approved for } \\
\text { MePS Reporting }\end{array}$ \\
\hline
\end{tabular}

